\section{EVALUATION OF PARAMETERS FOR SUBCRITICAL WATER EXTRACTION OF ZINGIBER ZERUMBET USING FRACTIONAL FACTORIAL DESIGN}

Siti Nur Khairunisa Mohd Amira, Mariam Firdhaus Mad Nordina*, Kamyar Shamelia, Izzati Mohamad Abdul Wahaba, Mariani Abdul Hamidb

aMalaysia-Japan International Institute of Technology, Universiti Teknologi Malaysia Kuala Lumpur, 54100, Kuala Lumpur, Malaysia bFakulti Kejuruteraan Kimia \& Kejuruteraan Sumber Asli, Universiti Teknologi Malaysia, 81310, UTM Johor Bahru, Johor, Malaysia
Article history

Received

9 January 2020

Received in revised form

5 December 2020

Accepted

6 December 2020

Published online

23 February 2021

*Corresponding author mariamfirdhaus@utm.my

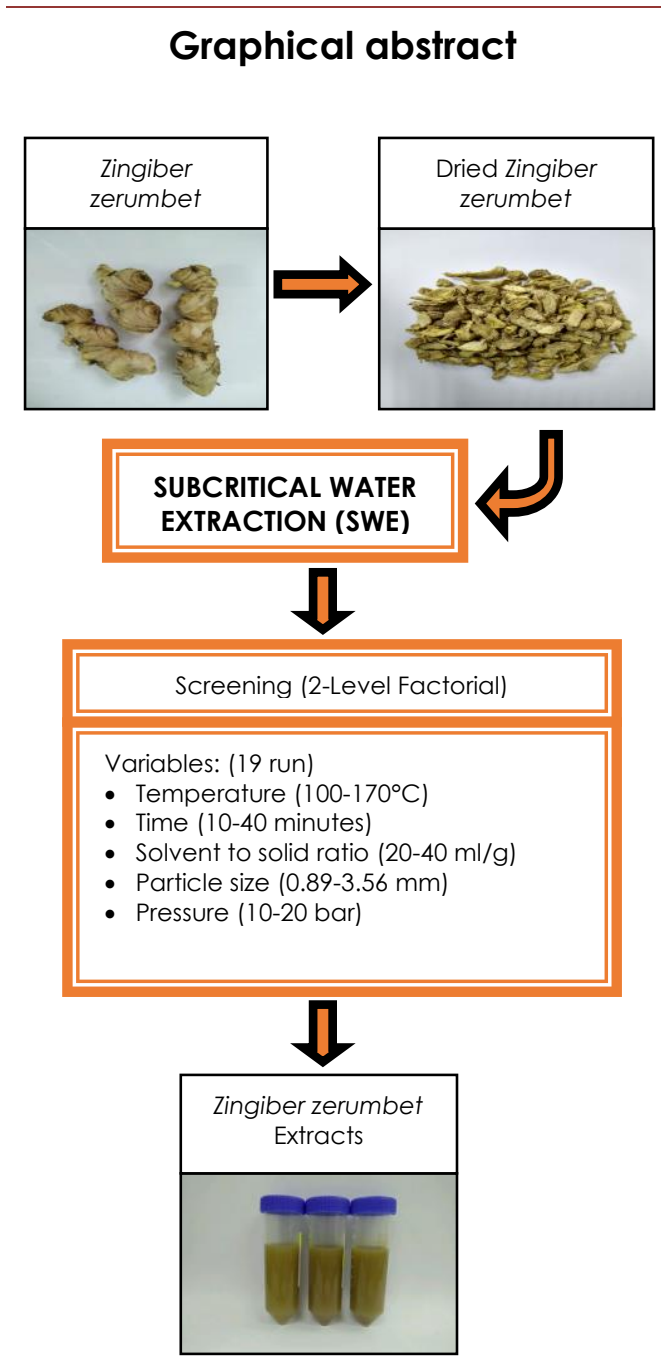

\begin{abstract}
Zingiber zerumbet (Z. zerumbet) is recognized for decades for its usability as spice and condiment in food flavoring as well as having high medicinal properties. Up to date, there are limited literature on evaluation of the effects of multiple variables in details especially in pilot-scale subcritical water extraction (SWE) of Z. zerumbet. The aim for this study is to implement the fractional factorial design with five variables which are temperature $(100-$ $170^{\circ} \mathrm{C}$ ), time (10-40 minutes), pressure (10-20 bar), particle size (0.89-3.56 mm) and solvent to solid ratio $(20-40 \mathrm{ml} / \mathrm{g})$ in SWE of Z. zerumbet. Analysis of variance for all responses stated that temperature, time, particle size and solvent to solid ratio are significant variables. Temperature is the most significant factor for zerumbone concentration and antioxidant activity with a $p$-value of $<0.0001$ and 0.0002 , respectively. The solvent to solid ratio was the most significant factor for the yield of extraction with a $p$-value of 0.0002 . Time and particle size were significant towards all responses, however pressure was not significant on zerumbone concentration and yield. Thus, the fractional factorial design could give a broad overview in selecting the significant variables for further optimization in SWE from the findings.
\end{abstract}

Keywords: Fractional factorial design, subcritical water extraction, Zingiber zerumbet, zerumbone concentration, antioxidant activity

\begin{abstract}
Abstrak
Zingiber zerumbet (Z. zerumbet) dikenali berdekad lamanya, digunakan sebagai rempah dan bahan di dalam perasa makanan serta mempunyai nilai perubatan yang tinggi. Sehingga kini, kajian yang terperinci berkenaan kesan pembolehubah untuk pengekstrakan air subgenting berskala pilot adalah terhad. Kajian ini dijalankan untuk melaksanakan rekabentuk faktorial pecahan dengan lima pembolehubah iaitu suhu $\left(100-170^{\circ} \mathrm{C}\right)$, masa $(10-40$ minutes), tekanan (10-20 bar), saiz bahan (0.89-3.56 mm) dan nisbah pelarut kepada pepejal $(20-40 \mathrm{ml} / \mathrm{g})$ dalam pengekstrakan air subgenting bagi $Z$. zerumbet. Analisis varians menyatakan bahawa pembolehubah termasuk suhu, masa, saiz bahan dan nisbah larutan kepada pepejal adalah signifikan terhadap respon. Suhu adalah paling signifikan terhadap kepekatan zerumbone dan aktiviti antioksida dengan nilai-p $<0.0001$ dan 0.0002 . Nisbah pelarut kepada pepejal paling signifikan untuk jumlah hasil ekstrak dengan
\end{abstract}


nilai-p 0.0002. Masa dan saiz bahan adalah signifikan terhadap semua respon, manakala tekanan didapati tidak signifikan untuk kepekatan zerumbone dan hasil pengekstrakan. Oleh itu, kajian ini sangat berguna dalam pemilihan pembolehubah untuk proses pengoptimuman selanjutnya dalam pengekstrakan air subgenting.

Kata kunci: Rekabentuk faktorial pecahan, pengekstrakan air subgenting, Zingiber zerumbet, kepekatan zerumbone, aktiviti antioksida.

(c) 2021 Penerbit UTM Press. All rights reserved

\subsection{INTRODUCTION}

Zingiber zerumbet (Z. zerumbet) locally called "Lempoyang" is lies under the Zingiberaceae family and extensively utilized throughout Asia in food and beverages. Besides its application as a food flavor, $Z$. zerumbet is traditionally consumed as home remedies for treating stomach discomfort and fever $[1,2]$. Z. zerumbet also possess high antioxidant activity which is beneficial for consumption [3, 4]. These important properties resulted from the bioactive compounds available in $Z$. zerumbet. Zerumbone is one of the major bioactive constituents in $Z$. zerumbet, which reported to possess the bioactivity beneficial for both in-vitro and in-vivo studies [5-8].

In order to obtain valuable properties of $Z$. zerumbet at its optimum condition, an extraction process is a critical aspect. Previously, several extraction processes of $Z$. zerumbet have been disclosed [9-11]. However, most of the methods are still implementing conventional extraction methods like Soxhlet extraction methods which involve organic solvent and hydrodistillation that take a longer time. Subcritical water extraction is an advanced extraction technique that uses water as extracting solvent at $100^{\circ} \mathrm{C}$ until $374^{\circ} \mathrm{C}$ with a pressure higher than atmospheric pressure in the range of $0.1 \mathrm{MPa}$ to 22.1 Mpa to ensure the water at its liquid condition during the extraction process [12-14]. Subcritical water extraction also demonstrated shorter extraction time (5-60 minutes) than conventional methods which could take at least 8 hours using the Soxhlet extraction method [15, 16]. In comparison to the other non-conventional method, supercritical fluid extraction, it is also required shorter time of experiments, however, it needs selective solvent and operates at the supercritical condition, compared to subcritical water extraction, which only uses water in subcritical condition [17-19].

Extraction process includes several parameters that need to be considered, and it could be temperature, time, pressure and others depending on the designated research. The screening process is the first step in determining the significant factors towards optimization [20]. There is a screening processes design to be chosen, such as fractional factorial, D-optimal, Plackett-Burman, and Taguchi
OA. Wong et al., 2014 successfully screened the significant variables in the extraction of palm kernel by implementing fractional factorial design for the further optimization process [21]. By utilizing screening process design, the number of the experiment will reduce, thus minimizing the usage of sample and solution related to the research $[22,23]$.

The present study explained the interaction between parameters including temperature, time, pressure, particle size, and solvent to solid ratio by employing fractional factorial design to analyze the most significant parameters in the pilot-scale subcritical water extraction of $Z$. zerumbet. This comprehensive research will give a short review of the interaction of multiple variables towards responses.

\subsection{METHODOLOGY}

\subsection{Chemicals and reagents}

Methanol HPLC grade and acetonitrile HPLC grade were purchased from Friendemann Schmidt Pty Ltd, Washington, US. 2,2-Diphenyl-1-picryl hydrazil (DPPH) was purchased from Sigma-Aldrich, US, and ethanol from J-Kollin, UK.

\subsection{Preparation of Zingiber zerumbet}

Z. zerumbet rhizomes were procured from a farm at Kuala Krau, Pahang, Malaysia. The samples were washed to remove soils and sliced to $1 \mathrm{~mm}$ thickness using the industrial slicer. Then, the sliced $Z$. zerumbet was dried in the oven at $50^{\circ} \mathrm{C}$ for three days. The final moisture of dried $Z$. zerumbet was measured using OHAUS Moisture Analyzer (MB25), USA to make sure it is dry enough to prevent the growth of microorganism and it lengthens the shelf life for storage purposes [24]. Before the extraction process, dried Z. zerumbet was ground to obtain a smaller size, and sieved. The sieved Z. zerumbet was categorized by mean particle size, which is calculated based on the sizes of sieve that dried $Z$. zerumbet entrapped $(4.75 \mathrm{~mm}, 2.36 \mathrm{~mm}, 1.18 \mathrm{~mm}, 600 \mu \mathrm{m})$. For a mean particle size of $0.89 \mathrm{~mm}$, the dried $Z$. zerumbet was entrapped between sieve sizes of $600 \mu \mathrm{m}$ and 1.18 $\mathrm{mm}$. 


\subsection{Subcritical water extraction of Zingiber zerumbet}

Subcritical water extraction of Zingiber zerumbet utilized in this research comprises of one extraction and one collection vessels. Both vessels equipped with pressure gauge and thermocouple for measuring pressure and temperature, respectively. The schematic diagram of $5 \mathrm{~L}$ subcritical water extraction is as illustrated in Figure 1.

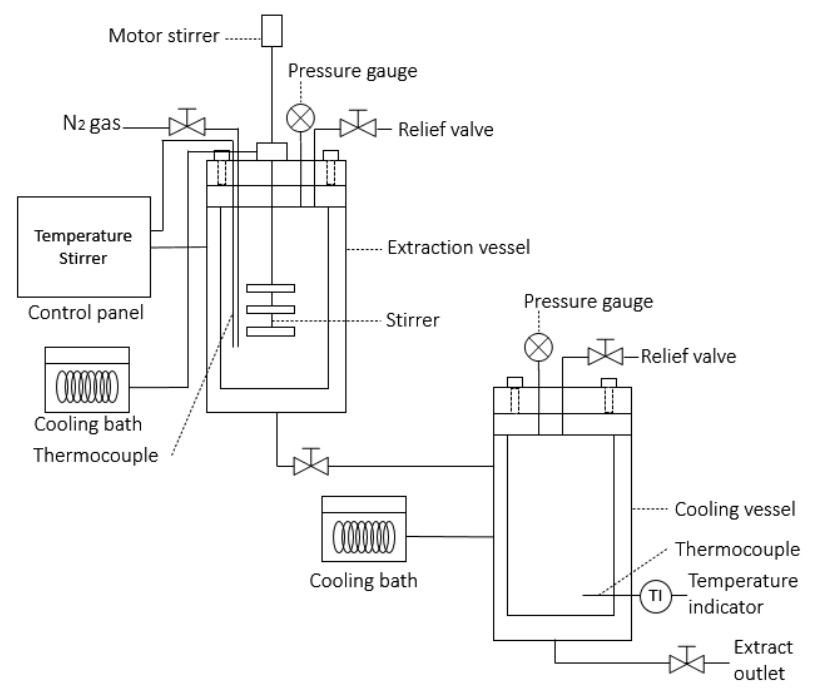

Figure 1 Schematic diagram of $5 \mathrm{~L}$ subcritical water extraction

The first step in this process was to insert the dried Z. zerumbet into a sample holder placed in the extraction vessel and filled with distilled water. The volume of distilled water was fixed at $2.5 \mathrm{~L}$; meanwhile, the weight of dried $Z$. zerumbet was varied based on the solvent to solid ratio for each run, as stated in Table 2. A fitted cover was fixed on top of the extraction vessel to prevent any pressure loss during the extraction process. Oxygenated oxygen available in the solution was purged with nitrogen gas for one minute. Then, the required pressure was maintained until the experiment completed. Finally, the extracts were streamed into the cooling vessels to be collected for the analysis.

\subsection{Fractional factorial design}

The fractional factorial or two-level half factorial design $\left(2^{5-1}\right)$ was employed using Design-Expert software (Version 7.1.6, Stat-Ease, Inc., MN). There are five variables namely temperature, time, pressure, particle size and solvent to solid ratio on pilot scale subcritical water extraction of $Z$. zerumbet $[10,25$, 26]. Three responses were evaluated from the experiments, which are yield, the concentration of zerumbone and antioxidant activity of the extracts. In order to perform these experiments, nineteen runs were required to identify all possible combinations of variables. The independent variables used in the fractional factorial design and the respective levels are shown in Table 1.

Table 1 Factors and levels of independent variables in a fractional factorial design

\begin{tabular}{lcccc}
\hline \multirow{2}{*}{ Independent variables } & Notation & \multicolumn{3}{c}{ Levels } \\
\cline { 3 - 5 } & & $\mathbf{- 1}$ & $\mathbf{0}$ & $\mathbf{1}$ \\
\hline Temperature $\left({ }^{\circ} \mathrm{C}\right)$ & $\mathrm{A}$ & 100 & 135 & 170 \\
\hline Time $(\mathrm{min})$ & $\mathrm{B}$ & 10.0 & 25.0 & 40.0 \\
\hline Pressure $(\mathrm{bar})$ & $\mathrm{C}$ & 10.0 & 15.0 & 20.0 \\
\hline Mean particle size $(\mathrm{mm})$ & $\mathrm{D}$ & 0.89 & 1.77 & 3.56 \\
\hline Solvent to solid ratio $(\mathrm{ml} / \mathrm{g})$ & $\mathrm{E}$ & 20.0 & 30.0 & 40.0 \\
\hline
\end{tabular}

2.5 High-performance Liquid Chromatography for Zerumbone Concentration

The concentration of zerumbone was analyzed using High-Performance Liquid Chromatography, HPLC (Waters 600-MS, USA) with Photodiode Array Detector (PDA) (Water, USA) and Lichrocart 250-4, 6 Purospher Star RP-8E (5 Mym) column (Merck, Germany). The mobile phases employed in this research are $100 \%$ methanol (solvent A) and $100 \%$ acetonitrile (solvent B) according to the modified procedure of [10]. The separation was carried out in isocratic elution with $35 \%$ (solvent A) and $65 \%$ (solvent B), monitored by PDA detector at a flow rate of $1 \mathrm{ml} / \mathrm{min}$ and wavelength of $254 \mathrm{~nm}$.

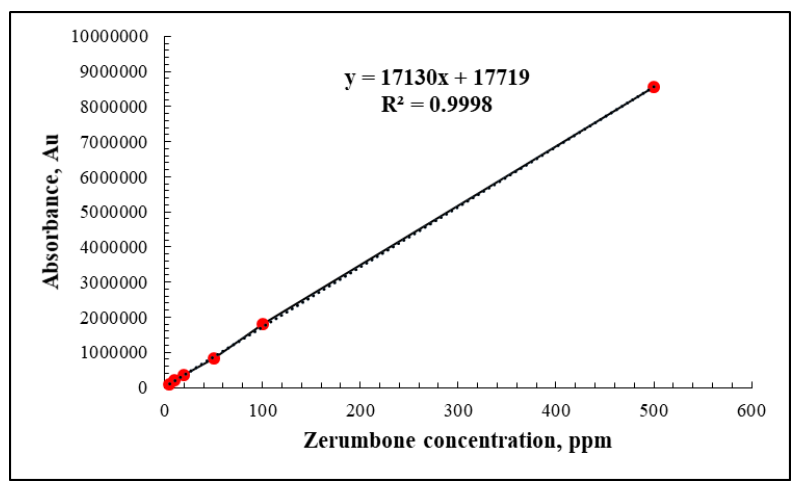

Figure 2 Zerumbone absorbance versus zerumbone concentration

On obtaining a standard calibration curve of zerumbone standards, six different concentrations which are 5, 10, 20, 50, 100 and 500 ppm were prepared. The standard was diluted with methanol. Linear regression was established on a calibration curve plotted by zerumbone absorbance against zerumbone concentration as in Figure 2. The purpose of HPLC analysis was to identify the zerumbone concentration in the extracts as zerumbone is the major bioactive compound found in Z. zerumbet [27, 6]. 


\subsection{Antioxidant Activity of Zingiber zerumbet Extract}

In order to identify the antioxidant activity of $Z$. zerumbet extracts, DPPH (1,1-diphenyl-2picrylhydrazyl hydrate, Sigma- Aldrich, Germany) was used to analyze the radical scavenging activity against the stable. $0.012 \mathrm{~g}$ of DPPH was dissolved in $300 \mathrm{ml}$ of $80 \%$ ethanol, and the solution was then kept in an amber glass bottle with a screw cap to prepare an ethanolic solution of DPPH. The absorbance of ethanolic DPPH as a control solution was taken at $517 \mathrm{~nm}$ using a spectrophotometer (UV1800, Shidmazu, Japan) equipped with a quartz cell (optical path length, $1 \mathrm{~cm}$ ) was utilized to measure the absorbance.

The liquid Z. zerumbet extracts were prepared by diluting in ethanol at a ratio of 1:4. These solutions were shaken vigorously for 1 minute using a vortex (Heidolph, Germany) and incubated in a dark environment at room temperature. After 1 hour, the absorbance of these solutions was measured at the same wavelength of the control solution. The percentage of antioxidant activity was calculated using Equation 1:

Antioxidant activity $(\%)=\frac{A-B}{A} \times 100 \quad$ (Equation 1)

Where $A$ is the absorbance of the DPPH control solution, and $\mathrm{B}$ is the absorbance of the DPPH control solution mixture with the Zingiber Zerumbet extract.

\subsection{Yield of Zingiber zerumbet Extract}

The yield of Zingiber Zerumbet extracts was obtained by a freeze-drying process to eliminate the solvent. The extracts were put in a beaker and stored in a freezer at $-80^{\circ} \mathrm{C}$. Then, the extracts were freeze-dried for three days to obtain the dried powder. The dried powder collected was placed in a freezer at the temperature of $-20^{\circ} \mathrm{C}$. The percentage of yield calculated based on weight to weight basis (w/w) as stated in Equation 2:

Yield $(\%)=\frac{W_{f}(g)-W_{i}(g)}{W_{s}(g)} \times 100$

(Equation 2)

Where $W_{f}$ is a weight of beaker with dried Zingiber zerumbet after the freeze-dried process completed, $W_{i}$ is the weight of empty beaker $(g)$ and $W_{s}$ is the weight of dried and ground Zingiber zerumbet.

\subsection{RESULTS AND DISCUSSION}

\subsection{Influence of Extraction Variables on Zerumbone} Concentration

The research outcomes are stated in Table 2, and the results were analyzed for each response studied. The most striking result to emerge from the data is that temperature was the most significant factor in zerumbone concentration as the p-value was $<0.0001$ with percentage contribution of $43.55 \%$ as recorded in Table 3. To compare the results on zerumbone concentration, only pressure was found to be insignificant as the $p$-value was 0.2646 , as stated in Table 4. For a variable or model to be significant, the p-value must less than 0.05 .

The final equation in coded factors for zerumbone concentration is stated in Equation 3.

Concentration $=+8.05+2.04 * A+1.08 * B-0.89 * D-1.04$ ${ }^{*} \mathrm{E}-0.39{ }^{*} \mathrm{~A} * \mathrm{~B}+0.18{ }^{*} \mathrm{~A} * \mathrm{C}-0.51{ }^{*} \mathrm{~A} * \mathrm{D}-0.58 * \mathrm{~A} * \mathrm{E}-0.034$ *B*C $-0.96 * B * D-0.32 * B * E+0.30 * C * D-0.61 * D * E$

(Equation 3)

Table 2 Fractional factorial design for five factors in the experiment

\begin{tabular}{|c|c|c|c|c|c|c|c|c|}
\hline \multirow{2}{*}{ Run } & \multicolumn{5}{|c|}{ Independent variables } & \multicolumn{3}{|c|}{ Responses } \\
\hline & A & B & C & D & $E$ & $Y_{1}$ & $Y_{2}$ & $Y_{3}$ \\
\hline 1 & 100 & 40.0 & 10.0 & 3.56 & 40.0 & 5.78 & 26.7 & 9.70 \\
\hline $2^{a}$ & 135 & 25.0 & 15.0 & 1.77 & 30.0 & 7.52 & 37.4 & 12.6 \\
\hline $3 a$ & 135 & 25.0 & 15.0 & 1.77 & 30.0 & 8.15 & 33.4 & 12.0 \\
\hline 4 & 100 & 40.0 & 10.0 & 0.89 & 20.0 & 9.43 & 34.2 & 14.0 \\
\hline 5 & 100 & 40.0 & 20.0 & 3.56 & 20.0 & 7.77 & 45.8 & 13.5 \\
\hline 6 & 100 & 10.0 & 10.0 & 0.89 & 40.0 & 4.78 & 29.5 & 9.90 \\
\hline 7 & 100 & 10.0 & 10.0 & 3.56 & 20.0 & 4.39 & 27.3 & 12.5 \\
\hline 8 & 170 & 40.0 & 10.0 & 0.89 & 40.0 & 11.9 & 44.6 & 14.0 \\
\hline 9 & 170 & 40.0 & 20.0 & 3.56 & 40.0 & 6.50 & 41.9 & 12.3 \\
\hline 10 & 170 & 40.0 & 10.0 & 3.56 & 20.0 & 9.17 & 45.8 & 12.9 \\
\hline 11 & 170 & 10.0 & 10.0 & 3.56 & 40.0 & 7.63 & 31.6 & 11.8 \\
\hline 12 & 170 & 10.0 & 20.0 & 3.56 & 20.0 & 11.6 & 43.1 & 13.4 \\
\hline 13 & 100 & 40.0 & 20.0 & 0.89 & 40.0 & 7.11 & 39.0 & 12.3 \\
\hline 14 & 100 & 10.0 & 20.0 & 3.56 & 40.0 & 4.73 & 25.7 & 8.40 \\
\hline $15^{a}$ & 135 & 25.0 & 15.0 & 1.77 & 30.0 & 8.56 & 36.2 & 12.4 \\
\hline 16 & 170 & 10.0 & 20.0 & 0.89 & 40.0 & 8.04 & 35.0 & 12.8 \\
\hline 17 & 100 & 10.0 & 20.0 & 0.89 & 20.0 & 4.48 & 30.4 & 11.2 \\
\hline 18 & 170 & 40.0 & 20.0 & 0.89 & 20.0 & 15.8 & 56.3 & 16.0 \\
\hline 19 & 170 & 10.0 & 10.0 & 0.89 & 20.0 & 10.6 & 47.3 & 14.0 \\
\hline
\end{tabular}

\subsection{Influence of Extraction Variables on Antioxidant} Activity

For antioxidant activity, all variables were found to be significant as the temperature was found to be the major influencing factor of $38.36 \%$, followed by time $(21.01 \%)$, solvent to solid ratio $(15.87 \%)$, pressure $(4.63 \%)$ and mean particle size $(3.57 \%)$. The final equation in coded factor is stated in Equation 4.

Antioxidant activity $=+37.35+5.44 * \mathrm{~A}+4.03 * \mathrm{~B}+1.89$ ${ }^{*} \mathrm{C}-1.65 * \mathrm{D}-3.50 * \mathrm{*}-1.01{ }^{*} \mathrm{~A} * \mathrm{C}-0.81{ }^{*} \mathrm{~A} * \mathrm{D}-1.41{ }^{*} \mathrm{~A} * \mathrm{E}$ $+2.08{ }^{*} B * C-0.23{ }^{*} B * E+1.26{ }^{*} C * D-0.72 * C * E-0.99 * D * E$

(Equation 4) 
Table 3 Percentage contribution of variables on responses

\begin{tabular}{cccc}
\hline \multirow{2}{*}{$\begin{array}{c}\text { Independent } \\
\text { variables }\end{array}$} & \multicolumn{3}{c}{ Percentage contribution, $\mathbf{1 0 0 \%}$} \\
\cline { 2 - 4 } & $\mathbf{Y}_{\mathbf{1}}$ & $\mathbf{Y}_{\mathbf{2}}$ & $\mathbf{Y}_{\mathbf{3}}$ \\
\hline $\mathrm{A}$ & 43.55 & 38.36 & 28.10 \\
\hline $\mathrm{B}$ & 12.12 & 21.01 & 13.05 \\
\hline $\mathrm{C}$ & 0.220 & 4.630 & 0.140 \\
\hline $\mathrm{D}$ & 8.400 & 3.570 & 10.37 \\
\hline $\mathrm{E}$ & 11.38 & 15.87 & 30.29 \\
\hline $\mathrm{AB}$ & 1.580 & 0.006 & 2.110 \\
\hline $\mathrm{AC}$ & 0.350 & 1.320 & 0.710 \\
\hline $\mathrm{AD}$ & 2.770 & 0.860 & 1.100 \\
\hline $\mathrm{AE}$ & 3.580 & 2.570 & 3.450 \\
\hline $\mathrm{BC}$ & 0.012 & 5.620 & 3.970 \\
\hline $\mathrm{BD}$ & 9.650 & 0.003 & 4.240 \\
\hline $\mathrm{BE}$ & 1.050 & 0.066 & 0.001 \\
\hline $\mathrm{CD}$ & 0.960 & 2.060 & 0.010 \\
\hline $\mathrm{CE}$ & 3.850 & 0.670 & 0.010 \\
\hline $\mathrm{DE}$ & 0.001 & 1.280 & 1.730 \\
\hline $\mathrm{A}$ & &
\end{tabular}

A - Temperature ( $\left.{ }^{\circ} \mathrm{C}\right)$; B - Time (min); C - Pressure (bar); D - Mean particle size $(\mathrm{mm}) ; E$ - Liquid to solid ratio $(\mathrm{ml} / \mathrm{g}) ; Y_{1}$ - Zerumbone concentration (mg/g); $Y_{2}-$ Antioxidant activity (\%); $Y_{1}-$ Yield (\%)

Table $4 \mathrm{p}$-value of respective variables and responses

\begin{tabular}{cccc}
\hline \multirow{2}{*}{ Response } & \multicolumn{3}{c}{$p$-value for response } \\
\cline { 2 - 4 } & $\mathbf{Y}_{\mathbf{1}}$ & $\mathbf{Y}_{\mathbf{2}}$ & $\mathbf{Y}_{\mathbf{3}}$ \\
\hline Model & 0.0008 & 0.0026 & 0.0014 \\
\hline $\mathbf{A}$ & $<0.0001$ & 0.0002 & 0.0002 \\
\hline B & 0.0007 & 0.0009 & 0.0011 \\
\hline C & 0.2646 & 0.0214 & 0.4330 \\
\hline $\mathbf{D}$ & 0.0014 & 0.0338 & 0.0016 \\
\hline $\mathbf{E}$ & 0.0008 & 0.0017 & 0.0002 \\
\hline $\mathbf{R}^{2}$ & 0.9947 & 0.9788 & 0.9927 \\
\hline
\end{tabular}

A - Temperature $\left({ }^{\circ} \mathrm{C}\right) ; \mathrm{B}$ - Time (min); C - Pressure (bar); D - Mean particle size $(\mathrm{mm})$; $E$ - Liquid to solid ratio $(\mathrm{ml} / \mathrm{g}) ; Y_{1}$ - Zerumbone concentration (mg/g); $Y_{2}$ - Antioxidant activity (\%); $Y_{3}-$ Yield (\%)

\subsection{Influence of Extraction Variables on Yield}

One surprising variable that was found to be the most significant associated with the yield of subcritical water extraction of $Z$. zerumbet was solvent to solid ratio with a percentage contribution of $30.29 \%$, which was slightly higher compared to temperature (28.10\%). It was compared with temperature because the temperature was found to be the most significant factor for zerumbone concentration and antioxidant activity in this research. The pressure was found to be insignificant since it is contributed only $0.14 \%$ towards the yield of extraction. The final equation for the yield of $Z$. zerumbet extract is stated in Equation 5.

Yield $=+12.37+0.98 * A+0.67 * B-0.59 * D-1.02 * E-0.27$

${ }^{*} A * B+0.16 * A * C-0.19 * A * D+0.34 * A * E+0.37 * B * C-0.38$

$* B * D+0.019 * C * D-0.24 * D * E$

(Equation 5)
3.4 Analysis of the Effects of Variables on Zerumbone Concentration, Antioxidant Activity and Yield of Extraction

The temperature was found to be the most significant factor for both zerumbone concentration and antioxidant activity. It could be seen from the large gradient of slope on the perturbation graph for the effect of temperature in Figure $3 a, 3 b$ and $3 c$ for zerumbone concentration, antioxidant activity, and yield respectively. These results are in line with those previous studies on subcritical water extraction that mentioned the temperature was one of the most significant factors [28, 29]. As water is used as a solvent in subcritical water extraction, temperature plays an important role. During the extraction process, once the temperature is increased, the viscosity and surface tension decrease, thus increasing diffusion characteristic of water [30, 31]. Turning now to the experimental evidence for the concentration of zerumbone resulting from the subcritical water extraction of Zingiber zerumbet in Table 2, Run $18\left(170^{\circ} \mathrm{C}\right)$ shows the maximum concentration of zerumbone at $15.76 \mathrm{mg} / \mathrm{g}$ compared to Run $7\left(100^{\circ} \mathrm{C}\right)$, which was the lowest of $4.39 \mathrm{mg} / \mathrm{g}$. However, further temperature increment will cause caramelization, Maillard reaction and hydrolysis to happen [32]. The interaction between temperature and time in the 3D surface graph also illustrated in Figure $4 a, 4 b$ and $4 c$ for each response. Each graph gives the same illustration pattern in which as the temperature and time increased, the values of each response also increased.

Solvent to solid ratio was found to be the most significant factor for the yield of the extraction process, and the large slope gradient illustrated it for the solvent to solid ratio in perturbation graph in Figure $3 \mathrm{c}$. From the finding, $20 \mathrm{ml} / \mathrm{g}$ of solid to solvent ratio produced the highest yield as in Run 18 (16\%) compared to $40 \mathrm{ml} / \mathrm{g}$, which only yielding $8.4 \%$ extracts as in Run 14. These results are consistent to the previous study on subcritical water extraction of Zingiber zerumbet in laboratory scale, which found the highest yield at $20 \mathrm{ml} / \mathrm{g}$ solvent to solid ratio compared to $10 \mathrm{ml} / \mathrm{g}$ [25]. These findings are significant, as it is in line with most of the paper that the sufficient solid-to-solvent ratio improved the contact between the sample and the solution, thereby improving the extraction process [33-35]. In addition, the maximum yield obtained in this subcritical water extraction is higher than the yield of Zingiber zerumbet extracts obtained by Soxhlet extraction from the previous study [3]. 
(a)

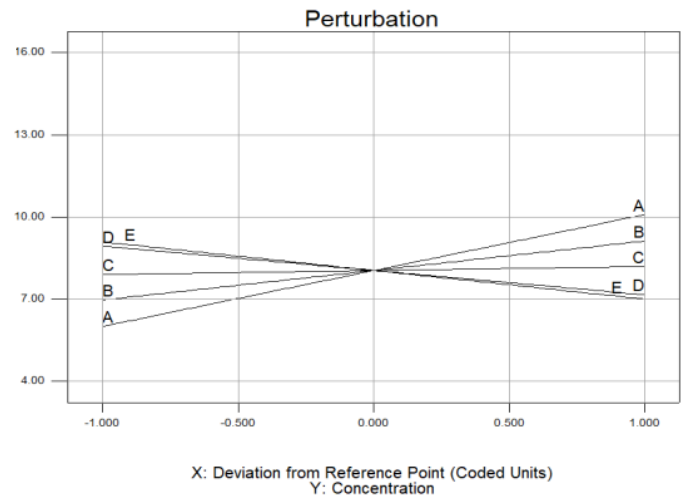

(b)

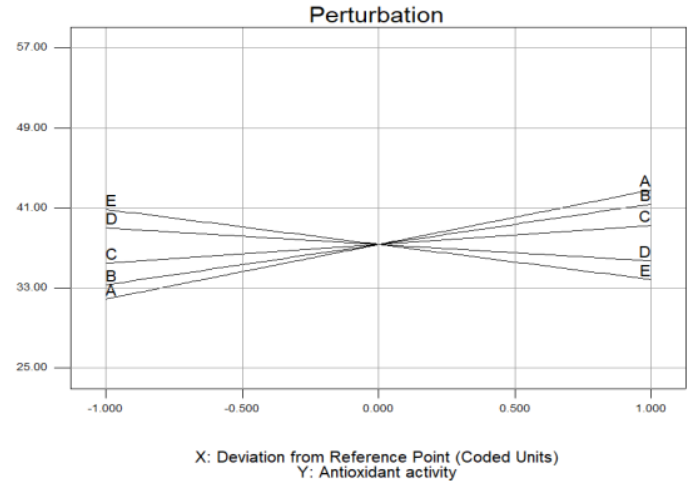

(c)

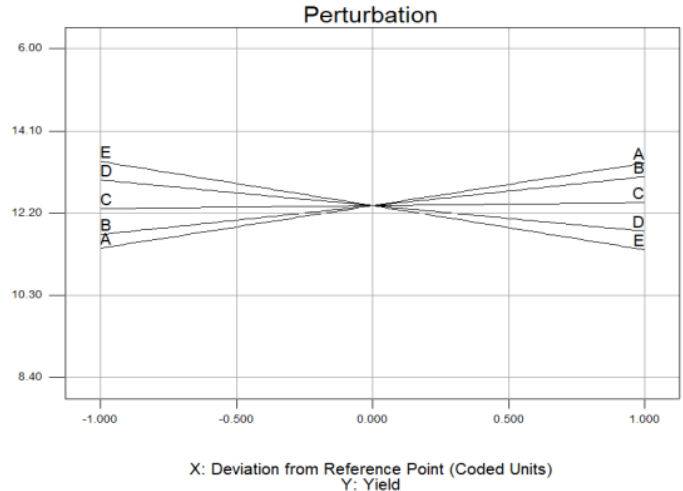

A - Temperature $\left({ }^{\circ} \mathrm{C}\right) ; \mathrm{B}$ - Time (min); C - Pressure (bar); D - Mean particle size $(\mathrm{mm}) ; \mathrm{E}-$ Liquid to solid ratio $(\mathrm{ml} / \mathrm{g})$

Figure 3 Perturbation graph for (a) zerumbone concentration, (b) antioxidant activity and (c) yield

Time was found to be significant after temperature and solid to solvent ratio for all responses [36]. Contact time of solvent and sample during the experiment is very important. Shorter extraction time will lead to an ineffective extraction; meanwhile, longer extraction time will cause degradation of the bioactive compound to be extracted [37]. It was proved that for 10 minutes of extraction, the results of zerumbone concentration in Run 7, together with both antioxidant activity and yield in Run 14, give the lowest values in results that are believed to be inadequate time to extracts all valuable properties in the sample. In contrast, for 40 minutes of extraction, highest zerumbone concentration was recorded at Run 18. This finding proves that by utilizing the subcritical water extraction, the extraction time was shorter than conventional methods to extract the valuable properties of the sample, especially in the extraction of $\mathrm{Z}$. zerumbet [38, 39].

(a)

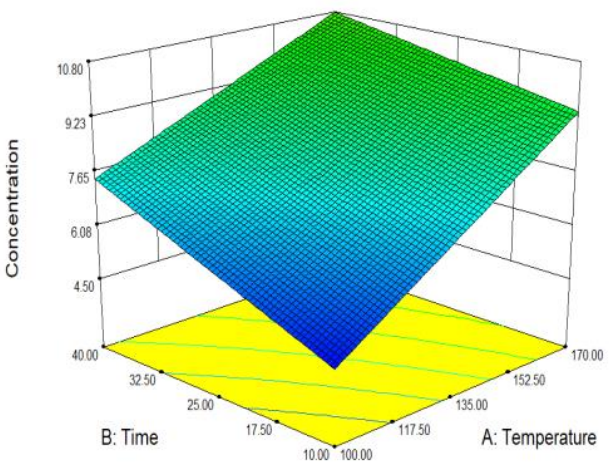

(b)

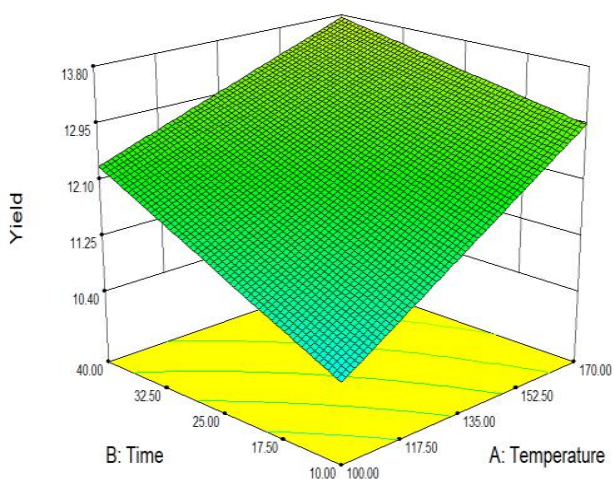

(c)

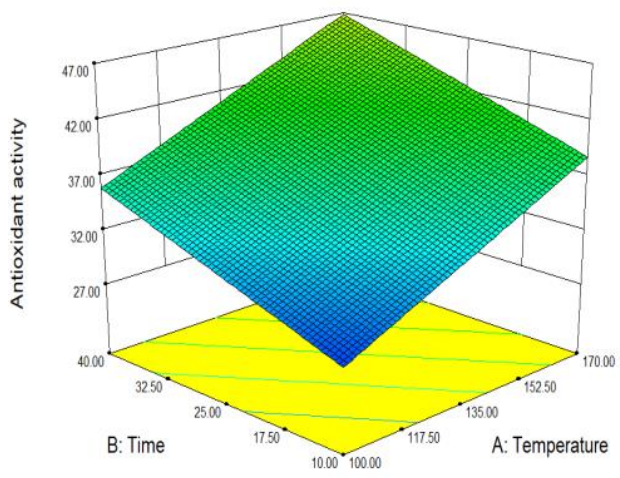

Figure 4 3D surface graph for (a) zerumbone concentration, (b) antioxidant activity and (c) yield

In this research, particle size was found to be significant in all responses studied. In most research, the smallest particle size affected the result the most $[12,40]$. It was verified in this research as the smallest mean particle size $0.89 \mathrm{~mm}$ at Run 18 resulted in the highest value of zerumbone concentration since smaller particle size will increase the surface area of the sample, thus increased the research efficiency [41].

The pressure was insignificant for both zerumbone concentration and yield of extraction, however 
significant for antioxidant activity. In most studies, pressure changes designed was identified to be not significant toward subcritical water extraction, however, sufficient pressure for subcritical water to happen is important in order to extracts the targeted bioactive compound in the sample [26]. Only the slight changes in pressure did not significantly affect the responses studied.

\subsection{CONCLUSION}

The present research aimed to screen the significant factors using the fractional factorial design of subcritical water extraction of Zingiber zerumbet. The findings clearly showed that temperature was the most significant factor for zerumbone concentration and antioxidant activity with $43.55 \%$ and $38.36 \%$ contribution respectively, meanwhile solvent to solid ratio plays the highest contribution with $30.29 \%$ in yield of Z. zerumbet extract. The contribution of each variable could also be observed from the perturbation graph, as if the contribution of factor is significant, the graph will illustrate the higher slope gradient. Time and particle size were also found to be significant toward responses. However, the pressure was found to be insignificant toward zerumbone concentration and yield of extraction, but significant toward antioxidant activity. In this research, the fractional factorial design successfully analyzed temperature, solvent to solid ratio, time and particle size as affecting variables for subcritical water extraction of $Z$. zerumbet and can be carried forward for the optimization process. The valuable findings of this research give a broad overview of the effects of each variable toward responses, thus highlighting the significant variables in subcritical water extraction for the further optimization procedure.

\section{Acknowledgement}

The authors would like to acknowledge the Ministry of Education (MOE) for the PRGS (4L676) grant. SHIZEN iKohza and Malaysia-Japan International Institute of Technology (MJIIT), Universiti Teknologi Malaysia (UTM) for all facilities provided. The authors would also like to thank AM Zaideen Ventures Sdn. Bhd., a UTM spin-off company (HALEA Skin Care) for providing technical support to conduct present research work.

\section{References}

[1] Koga, A. Y., Beltrame, F. L., \& Pereira, A. V. 2016. Several Aspects of Zingiber Zerumbet: A Review. Brazilian Journal of Pharmacognosy. 26(3): 385-391. https://doi.org/10.1016/j.bjp.2016.01.006.

[2] Prakash, R. O., Rabinarayan, A., \& Kumar, M. S. 2011. Zingiber Zerumbet (L.) Sm. A Reservoir Plant for
Therapeutic Uses: A Review. International Journal of Pharma World Research. 2(2): 1-23.

[3] Hasham-Hisam, R., Noor, N. M., Roslan, M. N., Sarmidi, M. R., \& Aziz, R. A. 2011 . Optimization of Extraction Conditions of Antioxidant Activity from Zingiber Zerumbet Oleoresin. Journal of Applied Sciences. 11(13): 2394-2399. https://doi.org/10.3923/jas.2011.2394.2399.

[4] Sidahmed, H. M. A., Hashim, N. M., Abdulla, M. A., Ali, H. M., Mohan, S., Abdelwahab, S. I., ... Vadivelu, J. 2015. Antisecretory, Gastroprotective, Antioxidant and AntiHelicobcter Pylori Activity of Zerumbone from Zingiber Zerumbet (L.) Smith. PLOS ONE. 10(3): 1-21. https://doi.org/10.1371/journal.pone.0121060.

[5] Hossain, M. E., Bhattacharjee, S. C., \& Enayetul Islam, M. D. 2011. Chemical Investigation on Zingiber zerumbet Sm. Frontiers in Natural Product Chemistry. 1: 185-187. https://doi.org/10.2174/978160805212710501010185.

[6] Noor Mohamad, N. F., \& Sirat, H. M. 2016. Isolation, Characterization and Modification of Zerumbone from Zingiber zerumbet. EProceedings Chemistry. 1 (1): 7-10.

[7] Rumiza, A. R., \& Azimathol, H. L. P. 2005. The Antiprofilerative Effect of Zingiber zerumbet Extracts Fractions on the Growth of Human Breast Carcinoma Call Lines. Malaysian Journal of Pharmaceutial Sciences. 3(1): 45-52.

[8] Singh, C. B., Nongalleima, K., Brojendrosingh, S., Ningombam, S., Lokendrajit, N., \& Singh, L. W. 2012. Biological and Chemical Properties of Zingiber zerumbet Smith: A Review. Phytochemistry Reviews. 11(1): 113-125. https://doi.org/10.1007/s1 $1101-011$ 1-9222-4.

[9] Chang, C. J., Liou, S. S., Tzeng, T. F., \& Liu, I. M. 2014. The Ethanol Extract of Zingiber Zerumbet Smith Attenuates Non-Alcoholic Fatty Liver Disease in Hamsters Fed on HighFat Diet. Food and Chemical Toxicology. 65: 33-42. https://doi.org/10.1016/j.fct.2013.11.048.

[10] Ghasemzadeh, A., Jaafar, H. Z. E., Rahmat, A., \& Swamy, M. K. 2017. Optimization of Microwave-assisted Extraction of Zerumbone from Zingiber zerumbet L. rhizome and Evaluation of Antiproliferative Activity of Optimized Extracts. Chemistry Central Journal. 11(5): 1-10. https://doi.org/10.1186/s13065-016-0235-3.

[11] Nik Norulaini, N. A., Anuar, O., Omar, A. K. M., Alkarkhi, A. F. M., Setianto, W. B., Fatehah, M. O., ... Zaidul, I. S. M. 2009. Optimization of sc co2 Extraction of Zerumbone from Zingiber Zerumbet. Food Chemistry. 114(2009): 702-705.

[12] Pavlić, B., Vidović, S., Vladić, J., Radosavljević, R., Cindrić, M., \& Zeković, Z. 2016. Subcritical Water Extraction of Sage (Salvia officinalis L.) by-products - Process Optimization by Response Surface Methodology. Journal of Supercritical Fluids. 116: 36-45.

https://doi.org/10.1016/j.supflu.2016.04.005

[13] Shalmashi, A., Golmohammad, F., \& Eikani, M. H. 2008. Subcritical Water Extraction of Caffeine from Black Tea Leaf of Iran. Journal of Food Process Engineering. $31(3)$ : 330-338. https://doi.org/10.1111/j.1745-4530.2007.00156.x.

[14] Zeković, Z., Vidović, S., Vladić, J., Radosavljević, R., Cvejin, A., Elgndi, M. A., \& Pavlić, B. 2014. Optimization of Subcritical Water Extraction of Antioxidants from Coriandrum Sativum Seeds by Response Surface Methodology. Journal of Supercritical Fluids. 95: 560-566. https://doi.org/10.1016/j.supflu.2014.09.004.

[15] Anurukvorakun, O. 2013. Factorial Design Applied to Subcritical Water Extraction for the Investigation of Flavonoids and Antioxidant Capacity of Gynura calciphila Kerr. Mahidol University Journal of Pharmaceutical Sciences. 40(2): 7-16.

[16] Mohd Rasidek, N. A., Mad Nordin, M. F., Yusof, Y. A. Tokuyama, H., \& Nagatsu, Y. 2018. Effect of Temperature on Rheology Behaviour of Banana Peel Pectin Extracted Using Hot Compressed Water. Jurnal Teknologi. 80(3): 97103. https://doi.org/10.11113/jt.v80.11467.

[17] Herrero, M., Cifuentes, A. and Ibañez, E. 2006. 'Sub- and Supercritical Fluid Extraction of Functional Ingredients from Different Natural Sources: Plants, Food-by-Products, Algae 
and Microalgae - A Review. Food Chemistry. 98: 136-148. https://doi.org/10.1016/j.foodchem.2005.05.058.

[18] Bimakr, M., Rahman, R. A., Ganjloo, A., Taip, F. S., Salleh, L. M. and Sarker, M. Z. I. 2011 . Optimization of Supercritical Carbon Dioxide Extraction of Bioactive Flavonoid Compounds from Spearmint (Mentha spicata L.) Leaves by Using Response Surface Methodology. Food and Bioprocess Technology. 5(3): 912-920. https://doi.org/10.1007/s1 1947-010-0504-4.

[19] Dang, Q. T. and Phan, N. N. 2014 Optimization of Supercritical $\mathrm{CO}_{2}$ Extraction of Oleoresin from Black Pepper (Piper nigrum L.) and Antioxidant Capacity of the Oleoresin. International Food Research Journal. 21(4): 1489-1493.

[20] Sandadi, S., Ensari, S., \& Kearns, B. 2006. Application of Fractional Factorial Designs to Screen Active Factors for Antibody Production by Chinese Hamster Ovary Cells. Biotechnology Progress. 22(2): 595-600. https://doi.org/10.1021/bp050300q.

[21] Wong, W. H., Lee, W. X., Ramanan, R. N., Tee, L. H., Kong K. W., Galanakis, C. M., ... Prasad, K. N. 2014. Two Level Half Factorial Design for the Extraction of Phenolics, Flavonoids and Antioxidants Recovery from Palm Kernel by-Product. Industrial Crops and Products. 63: 238-248. https://doi.org///dx.doi.org/10.1016/j.indcrop.2014.09.049.

[22] Arinkoola, A. O., \& Ogbe, D. O. 2015. Examination of Experimental Designs and Response Surface Methods for Uncertainty Analysis of Production Forecast: A Niger Delta Case Study. Journal of Petroleum Engineering. 1-16. https://doi.org/10.1155/2015/714541

[23] Telford, J. K. 2007. A Brief Introduction to Design of Experiments. Johns Hopkins APL Technical Digest (Applied Physics Laboratory). 27(3): 224-232.

[24] Zhang, M., Tang, J., Mujumdar, A. S., \& Wang, S. 2006. Trends in Microwave-related Drying of Fruits and Vegetables. Trends in Food Science and Technology. 17(10): 524-534. https://doi.org/10.1016/j.tifs.2006.04.011.

[25] Mohamad Abdul Wahab, I., Mad Nordin, M. F., \& Mohd Amir, S. N. K. 2019. Subcritical Water Extraction (SWE) of Zingiber zerumbet Using Two Level Full Factorial Design. Malaysian Journal of Fundamental and Applied Sciences. 15(2): 139-145.

[26] Valizadeh Kiamahalleh, M., Najafpour-Darzi, G., Rahimnejad, M., Moghadamnia, A. A., \& Valizadeh Kiamahalleh, M. 2016. High Performance Curcumin Subcritical Water Extraction from Turmeric (Curcuma longa L.). Journal of Chromatography B: Analytical Technologies in the Biomedical and Life Sciences. 1022: 191-198. https://doi.org/10.1016/j.jchromb.2016.04.021.

[27] Chien, T. Y., Chen, L. G., Lee, C. J., Lee, F. Y., \& Wang, C. C. 2008. Anti-inflammatory constituents of Zingiber zerumbet. Food Chemistry. 110(3): 584-589. https://doi.org/10.1016/j.foodchem.2008.02.038.

[28] M. Samidi, Z. Zainal Abidin, H. Yoshida, R. Yunus, D. R. Awang Biak, C. H. Lee \& E. H. Lok. 2019. Subcritical Water Extraction of Essential Oil from Aquilaria malaccensis leaves. Separation Science and Technology. 1-20. https://doi.org/10.1080/01496395.2019.1650768.

[29] M. Haghighi Asl \& M. Khahenoori. 2013. Subcritical Water Extraction. H. Nakajima (Ed.). Mass Transfer - Advances in Sustainable Energy and Environment Oriented Numerical
Modeling. BoD - Books on Demand. United Kingdom. InTech. http://dx.doi.org/10.5772/54993.

[30] Alghoul, Z. M., Ogden, P. B., \& Dorsey, J. G. 2017. Characterization of the Polarity of Subcritical Water. Journal of Chromatography A. 1486: 42-49. https://doi.org/10.1016/j.chroma.2016.12.072.

[31] Mustafa, A., \& Turner, C. 2011. Pressurized Liquid Extraction as a Green Approach in Food and Herbal Plants Extraction: A Review. Analytica Chimica Acta. 703(1): 818. https://doi.org/10.1016/j.aca.2011.07.018.

[32] Plaza, M., \& Turner, C. 2015. Pressurized Hot Water Extraction of Bioactives. TrAC - Trends in Analytical Chemistry. 71: 39-54. https://doi.org/10.1016/j.trac.2015.02.022

[33] Benjamin, M., Stéphane, R., Gérard, V., \& Pierre-Yves, P. 2017. Pressurized Water Extraction of Isoflavones by Experimental Design from Soybean Flour and Soybean Protein Isolate. Food Chemistry. 214: 9-15. https://doi.org/10.1016/j.foodchem.2016.07.053.

[34] Lefsih, K., Giacomazza, D., Dahmoune, F., Mangione, M. R., Bulone, D., San Biagio, P. L., ... Madani, K. 2017. Pectin from Opuntia ficus indica: Optimization of microwaveassisted Extraction and Preliminary Characterization. Food Chemistry. 221: 91-99. https://doi.org/10.1016/j.foodchem.2016.10.073

[35] Xu, D. P., Zheng, J., Zhou, Y., Li, Y., Li, S., \& Li, H. Bin. 2017. Ultrasound-assisted Extraction of Natural Antioxidants from the Flower of Limonium sinuatum: Optimization and Comparison with Conventional Methods. Food Chemistry. 217: 552-559. https://doi.org/10.1016/j.foodchem.2016.09.013.

[36] Mottahedin, P., Haghighi Asl, A., \& Khajenoori, M. 2016. Extraction of Curcumin and Essential Oil from Curcuma longa L. by Subcritical Water via Response Surface Methodology. Journal of Food Processing and Preservation. 1-9. https://doi.org/10.1111/jfpp.13095.

[37] Tian, Y., Wang, Y., Ma, Y., Zhu, P., He, J., \& Lei, J. 2017. Optimization of Subcritical Water Extraction of Resveratrol from Grape Seeds by Response Surface Methodology. Applied Sciences. 7(4): 321 https://doi.org/10.3390/app7040321

[38] Abdul, A. B., AbdelWahab, S. I., Al-Zubairi, A. S., Elhassan M. M., \& Murali, S. M. 2008. Anticancer and Antimicrobial Activities of Zerumbone from the Rhizomes of Zingiber zerumbet. International Journal of Pharmacology. 4(4): 301-304. https://doi.org/10.3923/ijp.2008.301.304.

[39] Nag, A., Bandyopadhyay, M., \& Mukherjee, A. 2013. Antioxidant Activities and Cytotoxicity of Zingiber zerumbet (L.) Smith Rhizome. Journal of Pharmacognosy and Phytochemistry. 2(3): 102-108.

[40] Wiboonsirikul, J., \& Adachi, S. 2008. Extraction of Functional Substances from Agricultural Products or Byproducts by Subcritical Water Treatment. Food Science and Technology Research. 14(4): 319-328. https://doi.org/10.3136/fstr.14.319.

[41] Ko, M.-J., Kwon, H.-L., \& Chung, M.-S. 2016. Pilot-scale Subcritical Water Extraction of Flavonoids from Satsuma Mandarin (Citrus unshiu Markovich) Peel. Innovative Food Science \& Emerging Technologies. 38: 175-181. https://doi.org/10.1016/j.ifset.2016.10.008. 